\title{
A Case of Recurrent Plasmacytoma with Endobronchial Involvement
}

\author{
Endobronşiyal Tutulum ile Birlikte Rekürren Plazmositom Olgusu
}

Hülya Deniz' ${ }^{1}$ Özlem Erçen Diken²

\section{Abstract}

Extramedullary plasmacytomas and/or endobronchial plasmacytomas are rare conditions. We present this case due to its rarity. The patient who was diagnosed with extramedullary plasmacytoma of the right vocal cord ten years ago and nasopharynx two years ago was referred to our unit with hemoptysis. A suspicious lesion was detected in the right intermediate bronchus in the thoracic computed tomography (CT) scan and bronchoscopy was performed. A wide-based polypoid lesion in the distal part of the right intermediate bronchus was observed. Examination of the biopsy samples from the endobronchial polypoid lesion showed the presence of plasmacytosis. Extramedullary plasmacytomas are those which involve any soft tissue other than the bone marrow with the upper respiratory tract, being the most frequent site of extramedullary involvement. There are only six cases of endobronchial plasmacytoma in the English literature.

Key words: Plasmacytoma, extramedullary plasmacytoma, endobronchial plasmacytoma.

\section{Özet}

Ekstramedüller plazmositom ve/veya endobronşiyal plazmositom çok nadir tanılardır. Bu olguyu plazmositomun bu nadir durumu nedeni ile sunuyoruz. On yıl önce sağ vokal kordda iki yıl önce nazofarenkste ekstramedüller plazmositom tanısı almış olan hasta kliniğimize hemoptizi nedeniyle yönlendirildi. Toraks bigisayarlı tomografisinde sağ ara bronşta şüpheli lezyon görülmesi üzerine bronkoskopi işlemine alındı. Bronkoskopide sağ ara bronş distalinde geniş tabanlı polipoid lezyon izlendi. Endobronşiyal polipoid lezyondan alınan biyopsi incelemesi plazmositozisi gösterdi. Extramedüller plazmositom kemik iliği dışında herhangi bir yumuşak dokuda yerleşmiş plazmositomdur ve üst solunum yolları en sık tutulan bölgelerdir. İngilizce literatürde sadece altı adet endobronşiyal plazmositom olgusu vardır.

Anahtar Sözcükler: Plazmositom, ekstramedüller plazmositom, endobronşiyal plazmositom.
Pulmonary involvement may be the initial sign of multiple myeloma or may occur due to a primary pulmonary plasmacytoma (PPP). In contrast to the poor prognosis of multiple myeloma with pulmonary involvement, PPPs are likely to have a better prognosis. In a patient series, the lower airway involvement was found to occur in $4.7 \%$ of the patients with multiple myeloma (1). Primary endobronchial plasmacytoma (PEP) is a much less frequent condition with only six cases reported in the

\section{English literature.}

Of these cases, two were treated with YttriumAluminum-Garnet (YAG) laser, three with surgical resection, and one with rigid bronchoscopic debulking using the argon plasma coagulation (APC) (2-7).

We present this rare PEP case due to the obscurity surrounding its definition, and absence of published diagnostic and therapeutic algorithms.

'Department of Chest Disease, Çorum State Chest Diseases Hospital, Çorum, Turkey

Çorum Bölge Göğüs Hastalıkları Hastanesi, Göğüs Hastalıkları Bölümü, Çorum

${ }^{2}$ Department of Chest Diseases, Hitit University, Corum, Turkey

${ }^{2}$ Hitit Üniversitesi, Göğüs Hastalıkları Bölümü, Çorum

Submitted (Başvuru tarihi): 30.07.2015 Accepted (Kabul tarihi): 03.11.2015

Correspondence (iletişim): Özlem Erçen Diken, Department of Chest Diseases, Hitit University, Çorum, Turkey

e-mail: oercen@hotmail.com

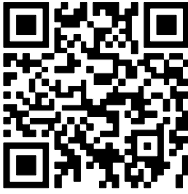




\section{CASE}

A 62-year-old male patient was diagnosed with an extramedullary plasmacytoma after histopathological examination of the biopsy specimen obtained from the right vocal cord 10 years ago. This was followed by local radiotherapy. Two years ago, he had another new-onset nasopharyngeal lesion, which proved to be a plasmacytoma after histopathological examination. Subsequent scans and bone marrow biopsy showed no involvement at other sites, shifting the focus of diagnosis from multiple myeloma to a plasmacytoma. Thus, he was readministered radiotherapy.

The patient presented to our unit with hemoptysis. Thoracic computed tomography (CT) showed a suspicious lesion in the right main bronchus and bronchoscopy was performed (Figure 1). The bronchoscopy showed a widebased polypoid lesion in the distal right main bronchus (Figure 2), as well as a mucosal irregularity at the upper third of the tracheal mucosa. The histopathological examination of the biopsy samples confirmed the diagnosis of amyloidosis in the tracheal lesion and a plasmacytoma in the endobronchial polypoid lesion.

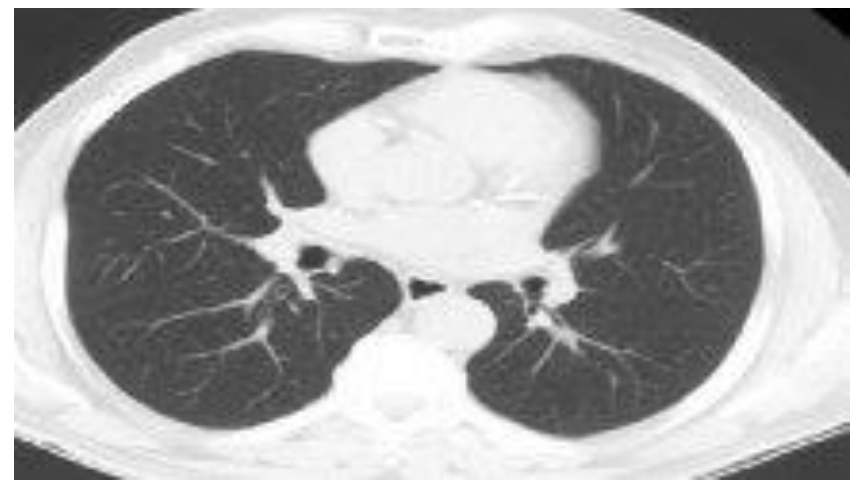

Figure 1: A suspected nodular lesion in the right main bronchus

A positron emission tomography (PET) showed no involvement in other sites or at the site of the endobronchial lesion. Bone marrow biopsies did not show any systemic involvement and the protein electrophoresis demonstrated monoclonal immunoglobulin lambda-band. Urinary immune-fixation electrophoresis showed a monoclonal band of lambda-light chain. A diagnosis of primary endobronchial pulmonary plasmacytoma was established on the basis of these findings. An endobronchial intervention was planned (YAG-laser). However, the patient refused further work-up and is currently under follow-up without any treatment.

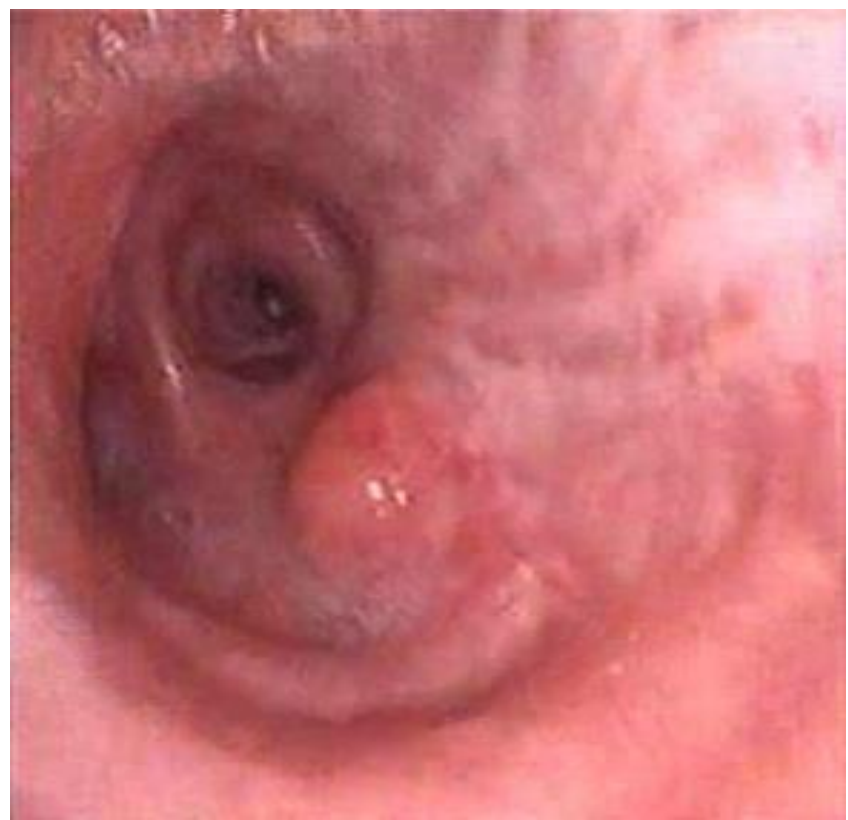

Figure 2: A polypoid lesion in the distal right main bronchus

\section{DISCUSSION}

Extramedullary plasmacytomas are plasma cell tumors which tend to arise from the mucosal lymphoid tissue of the upper airways. They may involve any soft tissue other than the bone marrow with the upper respiratory tract being the most frequent site of involvement (80\%) (8).

While the upper airway involvement is more common in men, no sex differences have been reported for pulmonary involvement (8). The most frequent radiological appearance are pulmonary nodules and mass lesions in the surrounding the hilus. Also, lobar consolidation and diffuse infiltration have been reported (1), as well as multiple pulmonary nodules (9) or cystic lung lesions (10). In our patient, we detected a suspicious pulmonary nodule and it was not clearly diagnostic. Therefore, the final diagnosis was able to be made only after bronchoscopy. An endobronchial involvement of plasmacytoma is not very well-known and often includes the mucosal involvement. In addition to rare polypoid tumors, it may also mimic a bronchogenic carcinoma. In our case, polypoid lesions were detected.

Also, some cases were diagnosed after thoracotomy performed for cystic lesions with a pre-diagnosis of aspergillosis $(8,10)$, as well as those diagnosed with videoassisted thoracoscopic surgery (11). In these patients, the histopathological diagnosis was based on immunohistochemical methods (lg kappa light chain monoclonality). After establishing a diagnosis of plasmacytoma with immunohistochemical analysis following surgical resection of the tumor, a diagnosis of multiple myeloma should also be performed to exclude multiple myeloma (8). In 
our case, the diagnosis was based on bronchoscopic biopsy and PET scanning and bone marrow biopsy were performed to rule out multiple myeloma.

No clearly-defined treatment protocols have been developed for this condition, yet. Some cases undergoing surgical treatment also receive radiotherapy, while others receive both chemotherapy and radiotherapy. On the other hand, some authors have reported good long-term survival and excellent results with surgery (10). The majority of the patients are treated with surgical resection alone (8). Radiotherapy is generally recommended for the plasmacytomas of the head and neck. Although there is no clear recommendation on the use of radiotherapy in the treatment of endobronchial plasmacytomas, some authors have suggested that endoscopic resection and laser may represent inadequate therapeutic options, necessitating the use of radiotherapy (2). In case of a primary endobronchial plasmacytoma, YAG-laser, surgical resection, and rigid bronchoscopic debulking with argon plasma coagulation (APC) can be used (2-7). In our case, laser-YAG treatment was offered. However, the patient did not give consent for the treatment and we were unable to perform laser-YAG treatment. Currently, he has been under our follow-up without treatment for two years. The most important prognostic factor in extramedullary plasmacytomas is the transformation into multiple myeloma. There is a lack of information on its prognosis, since no survival differences between different therapeutic modalities are unable to be shown (8).

Multiple or recurrent plasmacytomas may occur in $5 \%$ of the cases (1). In patients with multiple or frequent recurrences, systemic chemotherapy and autologous stem cell transplantation represent an important therapeutic option. In our case, an upper respiratory tract plasmacytoma was present in multiple locations and subsequently a pulmonary lesion was also detected.

In conclusion, a possibility of recurrence in patients who were previously diagnosed with an extramedullary plasmacytoma at another site should be kept in mind. Although an endobronchial plasmacytoma is a rare entity, it should be considered in the differential diagnosis of endobronchial neoplastic lesions. Treatment protocols and survival have not been clearly defined, yet.

\section{ACKNOWLEDGEMENTS}

We are thankful for the support of Oya Kayacan, MD, Prof of Chest Diseases. She answered kindly our questions about patient's diagnosis and writing this article.

\section{CONFLICTS OF INTEREST}

None declared.

\section{AUTHOR CONTRIBUTIONS}

Concept - H.D., Ö.E.D.; Planning and Design - H.D., Ö.E.D.; Supervision - H.D., Ö.E.D.; Funding -; Materials -; Data Collection and/or Processing - H.D.; Analysis and/or Interpretation - Ö.E.D.; Literature Review - Ö.E.D.; Writing - Ö.E.D.; Critical Review - Ö.E.D.

\section{YAZAR KATKILARI}

Fikir - H.D., Ö.E.D.; Tasarım ve Dizayn - H.D., Ö.E.D.; Denetleme - H.D., Ö.E.D.; Kaynaklar -; Malzemeler -; Veri Toplama ve/veya İşleme - H.D.; Analiz ve/veya Yorum - Ö.E.D.; Literatür Taraması - Ö.E.D.; Yazıyı Yazan Ö.E.D.; Eleştirel İnceleme - Ö.E.D.

\section{REFERENCES}

1. Montero C, Souto A, Vidal I, Fernández Mdel M, Blanco $M$, Verea $H$. Three cases of primary pulmonary plasmacytoma. Arch Bronconeumol 2009; 45:564-6. [CrossRef]

2. Wei S, Li X, Song Z, Zhao H, Qiu X, Gong L, et al. Primary endobronchial plasmacytoma involving local lymph nodes and presenting with rare immunoglobulin $G$ lambda monoclonal gammopathy. Can Respir J 2012; 19:e28-30. [CrossRef]

3. Woo Park C, Kim W, Jae Oh I, Sik Kim K, Duk Choi Y, Soo Kwon Y. Solitary extramedullary plasmacytoma presenting as an endobronchial mass. Intern Med 2013; 52:2113-6. [CrossRef]

4. Edelstein E, Gal AA, Mann KP, Miller JI Jr, Mansour KA. Primary solitary endobronchial plasmacytoma. Ann Thorac Surg 2004; 78: 1448-9. [CrossRef]

5. Piard F, Yaziii N, Jarry O, Assem M, Martin L, Bernard A, et al. Solitary plasmacytoma of the lung with light chain extracellular deposits: a case report and review of the literature. Histopathology 1998; 32:356-61. [CrossRef]

6. Brackett LE, Myers JR, Sherman CB. Laser treatment of endobronchial extramedullary plasmacytoma. Chest 1994; 106:1276-7. [CrossRef]

7. Terzi A, Furlan G, Zannoni M, Adovasio A, Gorla A. Endobronchial extramedullary plasmacytoma. Report of one case. Lung Cancer 1996; 16:95-100. [CrossRef]

8. Wise JN, Schaefer RF, Read RC. Primary pulmonary plasmacytoma: a case report. Chest 2001; 120:1405-7. [CrossRef] 
9. Kim SH, Kim TH, Sohn JW, Yoon HJ, Shin DH, Kim IS, et al. Primary pulmonary plasmacytoma presenting as multiple lung nodules. Korean J Intern Med 2012; 27:111-3. [CrossRef]

10. Huwer H, Jacobs G, Kalweit G, Püschel W. Solitary pulmonary plasmacytoma: report of two cases. Med Oncol 2010; 27:59-61. [CrossRef]
11. Osawa T, Yuyama K, Takahashi T, Tsubouchi Y, Egawa $\mathrm{K}$, Matsushita $\mathrm{H}$. A case of extramedullary plasmacytoma of the lung diagnosed by video-assisted thoracic surgery. Nihon Kokyuki Gakkai Zasshi 2011 ; 49:739-42. 